\title{
PENDUGAAN POTENSI DAN TINGKAT PEMANFAATAN IKAN LAYANG (Decapterus spp) DI PERAIRAN LAUT FLORES SULAWESI SELATAN
}

\author{
Husain Latukonsina \\ Staf Pengajar FPIK UNIDAR Ambon, $\boldsymbol{e}$-mail: husainlatuconsina@ymail.com
}

\begin{abstract}
ABSTRAK
Ikan Layang (Decapterus spp) adalah salah satu jenis sumberdaya perikanan pelagis kecil yang memiliki nilai ekonomis penting di perairan Laut Flores sehingga selalu menjadi tujuan penangkapan nelayan di Sulawesi Selatan khususnya pada kabupaten Selayar, Bulukumba, Bantaeng, Jeneponto dan Takalar. Berdasarkan hasil pendugaan stok dengan metode produksi surplus menggunakan data statistik perikanan tangkap periode 1999-2007, didapatkan nilai potensi lestari (MSY) sebesar 10.456 ton/tahun dengan upaya tangkap optimum $\left(f_{\text {opt }}\right)$ sebanyak 467.022 trip/tahun. Tingkat pemanfaatan rata-rata sebesar 76,60 \% dan tingkat pengupayaan sebesar $83,15 \%$. Status pemanfaatan sumberdaya ikan layang di perairan Laut Flores-Sulawesi Selatan sudah dikategorikan padat eksploitasi dengan tingkat pengupayan yang tinggi. Meskipun belum melewati nilai MSY dan $F_{\text {opt }}$ namun perlu kehati-hatian dalam pemanfataannya sehingga dapat dimanfaatakan secara maksimal dan berkelanjutan.
\end{abstract}

Kata Kunci: Ikan Layang, Potensi lestari, Tingkat pemanfaatan dan Pengupayaan

\section{PENDAHULUAN}

\subsection{Latar Belakang}

Ikan layang (Decapterus spp) merupakan sumberdaya ikan pelagis kecil yang berperan besar dalam sektor perekonomian nelayan di Sulawesi Selatan. Hal ini ditunjukan dari hasil tangkapan alat tangkap ikan-ikan pelagis seperti : purse seine, bagan, gill net, dan payang, dimana hasil tangkapan ikan layang sebesar 25.203,6 ton dengan nilai produksi Rp. 98.312 .840 pada tahun 2002 (Najamuddin (2004). Sementara keseluruhan potensi ikan layang di perairan Sulawesi Selatan menurut Widodo et al (1998) diduga sekitar 83.996,0 ton.

Selain dikonsumsi oleh masyarakat, ikan layang juga digunakan sebagai umpan pada alat penangkapan tuna long line lokal dan luar negeri. Berdasarkan data Statistik perikanan tahun 2001, produksi ikan layang di Sulawesi Selatan sebesar 42.857,4 ton. Ekspor ikan nelayan beku tercatat 75,4 ton dengan Negara tujuan Korea dan Jepang. Sedangkan permintaan untuk umpan perusahaan tuna long line sekitar 4.500 ton. Nelayan menangkap ikan layang mulai dari ukuran kecil sampai besar (mulai panjang 7,1 cm - 29,8 cm). Ikan layang berukuran kecil umumnya ditangkap dengan alat bagan, sementara ukuran sedang sampai besar ditangkap dengan purse seine, payang, gill net dan pancing (Najamuddin, 2004).

Salah satu wilayah penangkapan potensial sumberdaya ikan layang di Sulawesi Selatan adalah di Perairan Laut Flores, dimana nelayan Sulawesi Selatan kuhusunya pada 5 kabupaten (Selayar, Bulukumba, Bantaeng, Jeneponto dan Takalar) menjadikan perairan Laut Flores sebagai daerah potensi pelagis kecil, salah satunya adalah ikan layang (Decapterus). Dari data produksi tahunan periode tahun 1999-2007 terlihat adanya flutuasi penangkapan sumberdaya ikan layang, dimana hasil tangkapan yang tertinggi pada tahun 2006 sebesar 10.135 ton dan yang terendah pada tahun 2001 sebesar 5.150 ton, dengan rata-rata tangkapan pada sebesar 8.008,7 ton/tahun, sementara itu upaya pengkajian stok untuk menentukan satus perikanan layang di perairan Laut Flores-Sulawesi Selatan belum secara spesifik dilakukan sebagai informasi dasar untuk mengendalikan upaya penangkapan untuk kepentingan pengelolaannya.

Pengkajian stok (stock assessment) dalam setiap studi ilmiah perikanan adalah untuk menentukan produktivitas suatu sumberdaya 
perikanan, pengaruh penangkapan terhadap sumberdaya serta dampak dari perubahan pola penangkapan. Pendugaan kelimpahan stok sangat penting untuk mengevaluasi ukuran unit-unit pengelolaan, dan untuk menduga laju eksploitasi yang disebabkan oleh penangkapan (Gulland,1983).

Salah satu metode pendugaan kelimpahan yang sering digunakan di Indonesia adalah Metode produksi surplus. Ada dua pendekatan umum yang digunakan dalam Metode Produksi Surplus yaitu model linier Schaeffer dan model model eksponensial Fox. Dari metode ini dapat diperoleh estimasi potensi dari suatu jenis sumberdaya ikan. Penentuan potensi sumberdaya ikan tersebut dilakukan dengan menggunakan surplus yield method yang menitik-beratkan pada perbandingan hasil tangkapan dari beberapa jenis kelompok alat tangkap, yang dikaitkan dengan intensitas pemanfaatan dan kondisi lingkungan perairan (Gulland, 1983).

Analisis potensi lestari sumberdaya ikan yang didasarkan pada data produksi time series dan effort penangkapan adalah dengan menggunakan metode Produksi Surplus untuk mengitung potensi lestari (MSY) dengan cara menganalisis hubungan upaya penangkapan ikan (f) dengan hasil tangkapan (C) per satuan upaya (CPUE). Data yang digunakan berupa data hasil tangkapan (catch) dan upaya penangkapan (effort) dan pengolahan data melalui model Schaeffer dan Fox (Sparre and Venema 1999).

Berdasarkan permasalahan tersebut di atas maka diperlukan kajian pemanfaatan ikan Layang (Decapterus) di perairan Laut Flores-Sulawesi Selatan dengan menggunakan metode Produksi Surplus (model Schaefer dan Fox) untuk menghitung nilai potensi maksimum lestari (MSY), effort optimum $\left(f_{\text {opt }}\right)$, tingkat pemanfaatan dan tingkat pengupayaan, untuk kepentingan pengelolaan sumberdaya ikan Layang (Decapterus) di perairan Laut Flores-Sulawesi Selatan, agar dapat dimanfaatkan secara berkelanjutan.

\subsection{Tujuan Penelitian}

Penelitian ini bertujuan untuk:

1. Mengevaluasi jumlah potensi ikan layang diperairan Laut Flores-Sulawesi Selatan.

2. Melihat status pemanfaatan sumberdaya ikan laying di perairan Laut Flores-Sulawesi Selatan.

\section{METODE PENELITIAN}

\subsection{Waktu dan Tempat Penelitian}

Data yang digunakan adalah data sekunder, yang dikumpulkan pada bulan Mei 2010 di Dinas Perikanan dan Kelautan Provinsi Sulawesi Selatan, Makassar.

\subsection{Pengumpulan Data}

Data sekunder diperoleh dari Dinas Perikanan dan Kelautan Provinsi Sulawesi Selatan berupa estimasi hasil tangkapan beserta upaya penangkapan Ikan Layang pada perairan Laut Flores Sulawesi Selatan dengan menggunakan data statistik penangkapan dari 5 kabupaten, yaitu : Kabupaten Selayar, Bulukumba, Bantaeng, Jeneponto dan Takalar selama periode tahun 1999-2007.

\subsection{Analisa Data}

Metode produksi surplus digunakan dalam perhitungan potensi maksimun lestari (MSY) dan upaya penangkapan optimum $\left(\mathrm{f}_{\mathrm{opt}}\right)$ dengan cara menganalisis hubungan upaya penangkapan dengan hasil tangkapan per satuan upaya (CPUE).

Metode produksi surplus terdiri dari model Schaefer dan model Fox. Tidak dapat dibuktikan bahwa salah satu model tersebut lebih baik dari model yang lain. Pemilihan salah satu model didasarkan pada kepercayaan bahwa salah satu model tersebut paling rasional dan mendekati keadaan sebenarnya atau paling sesuai dengan data yang ada (Spare dan Venema 1999). Hal tersebut ditunjukkan oleh nilai $\mathrm{R}^{2}$ atau koefisien determinasi. Menurut Sokal dan Rohlf (1981) dalam Taeran (2007) koefisien determinasi adalah nilai yang menyatakan besarnya perubahan variabel y karena peubah variabel $\mathrm{x}$. Model yang memiliki nilai $\mathrm{R}^{2}$ terbesar adalah model yang sesuai untuk digunakan dalam menganalisis data tersebut karena menunjukkan bahwa peubah $\mathrm{x}$ berpengaruh besar terhadap peubah y.

\subsubsection{Hasil Tangkapan per Upaya Tangkapan (Catch per Unit Effort)}

Produktivitas suatu alat tangkap dapat diduga dengan melihat hubungan antara hasil tangkapan (catch) dengan upaya penangkapan (effort) disebut dengan Catch Per Unit Effort (CPUE). Dalam penelitian ini data catch adalah data hasil tangkapan ikan layang dari 13 jenis alat tangkap dan upaya penangkapan (effort) berupa jumlah trip.

Persamaan untuk mencari nilai CPUE adalah sebagai berikut (Gulland, 1983): 
$\mathrm{CPUE}=\frac{C t}{f t}$

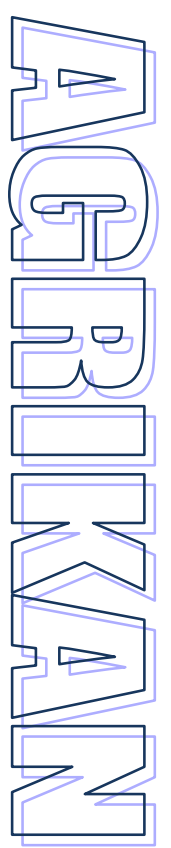

Keterangan :

CPUE $=$ Catch per Unit Effort

$\mathrm{C}_{\mathrm{t}} \quad=$ Hasil tangkapan pada tahun ke- $t$ (ton)

$f_{\mathrm{t}} \quad=$ Upaya penangkapan pada tahun ke- $t$ (trip)

Selanjutnya dilakukan pengolahan data melalui pendekatan Model Schaefer dan Fox. Model ini merupakan model analisis regresi dari CPUE terhadap jumlah effort. untuk mengetahui potensi maksimum lestari (Maximum Sustainable Yield/MSY) dan Effort Optimum $\left(f_{\text {opt }}\right)$ terhadap sumberdaya ikan layang (Decapterus) di perairan Laut Flores Sulawesi Selatan. Analisa dilakukan menggunakan Microsoft Exel 2007.

Secara umum tahapan pengolahan data metode Produksi Surplus, sebagai berikut:

1. Membuat tabulasi hasil tangkapan $($ catch $=\mathrm{C})$ beserta upaya penangkapan (effort $=f)$, kemudian dihitung nilai hasil tangkapan per satuan upaya penangkapan $(C P U E=$ Catch Per Unit Effort).

2. Jika ada beberapa macam alat tangkap yang digunakan, maka dilakukan standarisasi alat tangkap. Alat tangkap dominan dijadikan standar, sedangkan alat tangkap lain dikonversikan dalam alat tangkap standar.

3. Memplotkan nilai $\mathrm{f}$ terhadap nilai $\mathrm{c} / \mathrm{f}$ dan menduga nilai intercept (a) dan slope (b) dengan regresi linier.

4. Menghitung pendugaan potensi lestari (Maximum Sustainable Yield $=$ MSY) dan upaya optimum (effort optimum $=$ Fopt $)$.

Besarnya parameter a dan $b$ secara matematik dapat dicari dengan menggunakan persamaan regresi linier sederhana dengan rumus $\mathrm{Y}=\mathrm{a}+\mathrm{bx}$. Persamaan Produksi Surplus hanya berlaku bila parameter b bernilai (-), artinya penambahan upaya penangkapan akan menyebabkan penurunan CPUE.

\subsubsection{Standardisasi Alat Tangkap}

Standarisasi alat tangkap dalam rangka menghitung potensi sumberdaya ikan penting dilakukan mengingat di wilayah tropis setiap jenis ikan dapat ditangkap dengan menggunakan lebih dari satu jenis alat tangkap. Alat tangkap yang ditetapkan sebagai alat tangkap standar dipilih dari alat tangkap yang mempunyai nilai produktivitas (CPUE) tertinggi.

Tampubolon (1991) dalam Imron (2008) menjelaskan bahwa alat tangkap yang ditetapkan sebagai alat tangkap standar mempunyai faktor daya tangkap atau Fishing Power Index yang sama dengan satu $(\mathrm{FPI}=1)$. Jenis alat tangkap lain dapat dihitung nilai daya tangkapnya dengan membagi hasil tangkapan per satuan upaya penangkapan (CPUE) alat tangkap tersebut dengan $C P U E$ dari alat tangkap standar. Nilai daya tangkap kemudian digunakan untuk mencari upaya standar (Standar effort) yaitu dengan mengalikan nilai FPI dan upaya penangkapan alat tersebut.

Persamaan yang digunakan adalah sebagai berikut :

$$
\begin{aligned}
& \mathrm{CPUE}=\frac{C t}{f t} \quad \mathrm{CPUE}_{\mathrm{s}}=\frac{C s}{f s} \\
& \mathrm{FPI}_{i}=\frac{\text { CPUE } i}{\text { CPUES }} \\
& \mathrm{FPI}_{\mathrm{s}}=\frac{\text { CPUES }}{\text { CPUES }} \\
& \text { Standar Effort } t_{i}=F P I_{i} \times f i, \ldots \\
& \text { Standart Effort } t_{s}=\text { FPIs } \mathrm{x} f s
\end{aligned}
$$

Keterangan :

$$
\begin{aligned}
& \text { Cs =Hasil tangkapan (catch) per tahun alat } \\
& \text { tangkap standar (ton) } \\
& f_{S} \quad=\text { Upaya penangkapan (effort) per tahun } \\
& \text { alat tangkap standar (trip) } \\
& \mathrm{C} t=\text { Hasil tangkapan }(\text { catch) per tahun jenis } \\
& \text { alat tangkap lain (ton) } \\
& f t=\text { Upaya penangkapan (effort) per tahun } \\
& \text { alat tangkap lain (trip) }
\end{aligned}
$$

\subsubsection{Pendugaan Potensi Lestari (MSY) dan Effort Optimum $\left(f_{\text {opt }}\right)$}

Data yang digunakan dalam metode Produksi Surplus berupa hasil tangkapan (catch) dan upaya penangkapan (effort) dan kemudian dilakukan pengolahan data melalui pendekatan Model Schaefer dan Model Fox. Model Schaefer dan Fox merupakan model analisis regresi dari CPUE terhadap jumlah effort.

a. Model Schaefer :

Hubungan antara $C$ (hasil tangkapan) dan $f$ (upaya penangkapan) adalah :

$$
C=a f+b(f)^{2},
$$

Nilai Upaya Optimum $\left(f_{\text {opt }}\right)$ adalah :

$$
\text { fopt }=-(a / 2 b),
$$

Nilai Potensi Maksimum Lestari (MSY) adalah :

$$
M S Y=-a 2 / 4 b,
$$




\section{b. Model Fox}

Hubungan antara $C$ (hasil tangkapan) dan $f$ (upaya penangkapan) adalah :

$$
C=f \exp (a+b(f),
$$

Nilai Upaya Optimum ( $f$ opt $)$ adalah :

$$
f_{o p t}=-(1 / b) \exp ^{(a-1)}
$$

Nilai Potensi Maksimum Lestari (MSY) adalah :

$M S Y=-1 / b$,

Keterangan :

$C=$ Jumlah hasil tangkapan per satuan upaya penangkapan (ton/trip)

$a \quad=$ Intercept

$\mathrm{b} \quad=$ Slope

$f \quad=$ Upaya penangkapan (trip) pada periode ke-i.

$f_{\text {opt }} \quad=$ Upaya penangkapan optimal (trip)

$M S Y=$ Nilai potensi maksimum lestari (ton/tahun).

\subsubsection{Pendugaan Tingkat Pemanfaatan dan Pengupayaan}

Pendugaan tingkat pemanfaatan dilakukan untuk mengetahui seberapa besar tingkat pemanfaatan sumberdaya ikan layang di perairan Laut Flores-Sulawesi Selatan. Pendugaan dilakukan dengan cara mempresentasikan jumlah hasil tangkapan pada tahun tertentu dengan nilai potensi maksimum lestari (MSY).

Persamaan dari tingkat pemanfaatan adalah (Paully 1983 dalam Astuti, 2005):

$$
\mathrm{TP}_{\mathrm{c}}=\frac{C i}{M S Y} x 100 \%
$$

Keterangan :

$$
\begin{aligned}
\mathrm{TP}_{\mathrm{c}}= & \text { Tingkat pemanfaatan pada tahun ke-i } \\
& (\%) \\
\mathrm{C}_{i} & =\begin{array}{l}
\text { Hasil tangkapan ikan pada tahun ke-i } \\
\text { (ton) }
\end{array} \\
M S Y= & \text { Maximum Sustainable Yield (ton) }
\end{aligned}
$$

Pendugaan tingkat pengupayaan dilakukan untuk mengetahui tingkat upaya tangkap sumberdaya ikan layang di perairan Laut FloresSulawesi Selatan. Pendugaan dilakukan dengan mempresentasekan effort standar pada tahun terterntu dengan nilai effort optimal (fopt).

Persamaan dari Tingkat Pengupayaan adalah :

$$
\mathrm{TP}_{\mathrm{f}}=\frac{f s}{\text { fopt }} \times 100 \%
$$

Keterangan :

$\mathrm{TP}=$ Tingkat Pengupayaan pada tahun ke-i (\%)

$f_{\mathrm{s}} \quad=$ Upaya Penangkapan (Effort Standar) pada tahun ke-i (trip)

$f_{\mathrm{opt}}=$ Upaya Penangkapan Optimum (ton/thn)

\section{HASIL DAN PEMBAHASAN}

\subsection{Produksi dan Produkstivitas Alat \\ Tangkap}

Jumlah jenis alat tangkap yang digunakan untuk menangkapan sumberdaya ikan layang (Decapterus) di perairan Laut Flores-Sulawesi Selatan khususnya yang digunakan oleh nelayan pada 5 kabupaten (Selayar, Bulukumba, Bantaeng, Jeneponto, dan Takalar) sebanyak 13 jenis alat tangkap, yaitu : Payang, Pukat Pantai, Pukat Cincin, Jaring Insang hanyut, Jaring Lingkar, Jaring Insang Tetap, Jaring Tiga Lapis, Bagan perahu, Bagan Tancap, Rawai hanyut, Rawai Tetap, Pancing lain dan Sero. Setiap jenis alat tangkap memiliki kemampuan menangkap yang berbeda, dari ke 13 jenis alat tangkap yang digunakan, pukat cincin (purse seine) memiliki kemampuan menangkap yang paling besar, terlihat dari produksi tertinggi selama periode tahun 1999-2007 pada Tabel 1.

Selama kurun waktu 1999-2007, produksi penangkapan ikan layang di Laut Flores-Sulawesi selatan, cukup berfluktuatif dan mengalami perkembangan seiring dengan penambahan upaya (effort) dalam bentuk trip penangkapan.

Dari ke 13 jenis alat tangkap yang di operasikan nelayan, Pukat Cincing (Purse seine) memiliki produktivitas tertinggi terhadap ikan layang selama periode 1999-2007, berdasarkan nilai rata-rata CPUE 0.0357 ton/trip. Tingginya produktivitas Pukat Cincin karena selain mendominasi penangkapan ikan layang dari tahun ke tahun, alat tangkap ini juga dikenal memiliki daya tangkap yang besar setiap kali melakukan penangkapan.

Berdasarkan nilai CPUE pada Gambar 1, dapat dipastikan bahwa jenis ikan layang sebetulnya dapat ditangkap dengan menggunakan beberapa jenis alat tangkap yang spesifik salah satunya yaitu pukat cincin. Dengan menggunakan alat tangkap spesifik diharapkan dapat menghindari tingginya hasil tangkapan sampingan yang dapat menurunkan stok sumberdaya laut lainnya yang bukan menjadi tujuan penangkapan.

Dalam rangka optimalisasi pemanfaatan sumberdaya ikan layang (Decapterus) di perairan Laut Flores-Sulawesi Selatan dan upaya keberlangsungannya maka perlu adanya penentuan beberapa jenis alat tangkap yang cocok untuk setiap jenis ikan. Keuntungan yang diharapkan adalah nelayan mendapatkan hasil tangkapan sesuai dengan yang diharapkan, dan sumberdaya ikan tidak mengalami tekanan dari berbagai alat tangkap yang tidak produktif. 
Tabel 1. Produksi Hasil Tangkapan ikan layang per jenis alat tangkap per tahun (periode 1999-2007).

\begin{tabular}{|c|c|c|c|c|c|c|c|c|c|c|c|c|}
\hline \multirow{2}{*}{ No } & \multirow{2}{*}{$\begin{array}{c}\text { Jenis Alat } \\
\text { Tangkap }\end{array}$} & \multicolumn{9}{|c|}{ Produksi Ikan Layang (Ton) } & \multirow{2}{*}{ Total } & \multirow{2}{*}{$\begin{array}{l}\text { Rata- } \\
\text { Rata }\end{array}$} \\
\hline & & 1999 & 2000 & 2001 & 2002 & 2003 & 2004 & 2005 & 2006 & 2007 & & \\
\hline 1 & Payang & 399,8 & 278,1 & 291,9 & 317,2 & 202,1 & 43,8 & 91,7 & 92,4 & 101,9 & 1818,8 & 202,09 \\
\hline 2 & Pukat Pantai & 317,1 & 297,0 & 534,1 & 485,1 & 688,3 & 667,9 & 132,9 & 133,3 & 115,6 & 3371,4 & 374,60 \\
\hline 3 & Pukat Cincin & 647,6 & 3574 & 1492,5 & 1328,9 & 3266,4 & 4071,9 & 4789,3 & 5250,6 & 5398,9 & 29820,1 & 3313,35 \\
\hline 4 & $\begin{array}{l}\text { Jaring insang } \\
\text { Hanyut }\end{array}$ & 794,7 & 456,2 & 739,0 & 778,7 & 1059,5 & 1270,5 & 1091,2 & 1118,8 & 1188,2 & 8496,8 & 944,08 \\
\hline 5 & Jrng lingkar & 208,3 & 192,9 & 332,5 & 409,4 & 915,6 & 571,4 & 542,7 & 567,2 & 554,7 & 4294,8 & 477,20 \\
\hline 6 & $\begin{array}{l}\text { Jrng insang } \\
\text { tetap }\end{array}$ & 762,4 & 439,4 & 466,6 & 960,4 & 1235,0 & 1297,2 & 1292,8 & 1364,2 & 1286,5 & 9104,5 & 1011,61 \\
\hline 7 & $\begin{array}{l}\text { Jrng tiga } \\
\text { lapis }\end{array}$ & 0,0 & 0,2 & 0,0 & 0,0 & 0,0 & 0,0 & 0,0 & 0,0 & 0,0 & 0,2 & 0,02 \\
\hline 8 & $\begin{array}{l}\text { Bagan } \\
\text { Perahu }\end{array}$ & 12,9 & 24,7 & 38,5 & 160,4 & 98,7 & 36,2 & 7,3 & 7,7 & 133,2 & 519,6 & 57,74 \\
\hline 9 & $\begin{array}{l}\text { Bagan } \\
\text { Tancap }\end{array}$ & 129,8 & 80,4 & 89,3 & 101,0 & 61,1 & 43,8 & 49,1 & 53,7 & 58,9 & 667,1 & 74,13 \\
\hline 10 & $\begin{array}{l}\text { Rawai } \\
\text { Hanyut }\end{array}$ & 185,3 & 22,8 & 50,3 & 67,8 & 196,0 & 184,2 & 16,2 & 171,8 & 176,5 & 1071,0 & 119,00 \\
\hline 11 & Rawai Tetap & 1051,2 & 300,8 & 618,5 & 699,9 & 1163,9 & 544,3 & 567,4 & 570,7 & 429,2 & 5945,9 & 660,65 \\
\hline 12 & Pancing Lain & 1843,1 & 491,9 & 467,1 & 518,4 & 675,0 & 543,4 & 913,8 & 804,7 & 509,3 & 6766,9 & 751,88 \\
\hline 13 & Sero & 78,4 & 26,5 & 29,5 & 33,5 & 33,4 & 51,9 & 157,0 & 27,6 & 20,1 & 458,0 & 50,89 \\
\hline
\end{tabular}

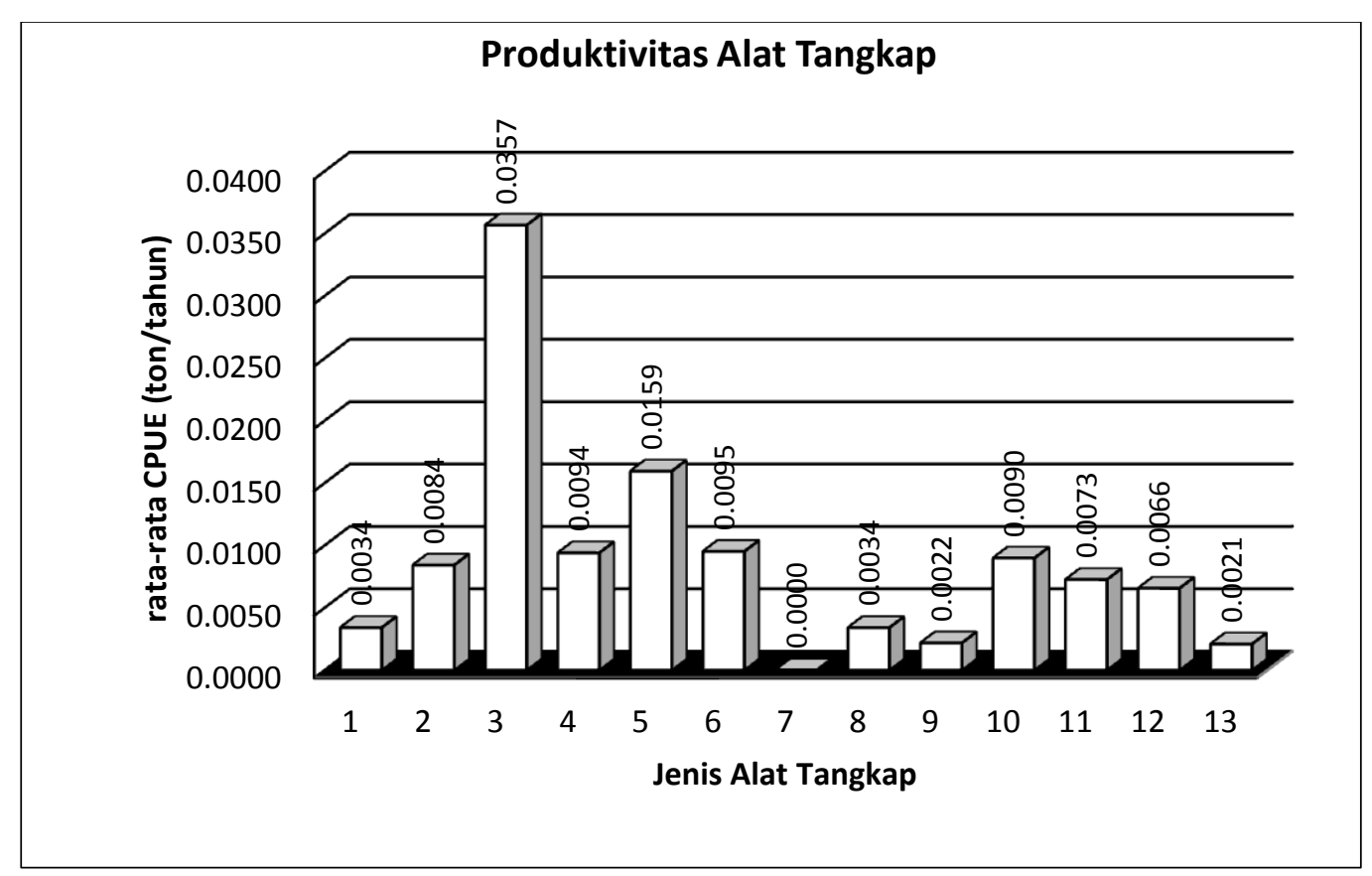

Keterangan: 1. Payang, 2.Pukat Pantai, 3.Pukat Cincin, 4.Jr.Insang hanyut, 5.Jaring Lingkar, 6. Jr.Insang tetap, 7.Jaring tiga lapis, 8.Bagan perahu, 9.Bagan tancap, 10.Rawai hanyut, 11.Rawai tetap, 12.Pancing lain, 13.Sero

Gambar 1. Produktivitas Alat Tangkap ikan Layang (Decapterus)selama periode tahun 1999. 2007 berdasarkan nilai rata-rata CPUE (ton/tahun).

Berdasarkan nilai CPUE pada Gambar 1, dapat dipastikan bahwa jenis ikan layang sebetulnya dapat ditangkap dengan menggunakan beberapa jenis alat tangkap yang spesifik salah satunya yaitu pukat cincin. Dengan menggunakan alat tangkap spesifik diharapkan dapat menghindari tingginya hasil tangkapan sampingan yang dapat menurunkan stok sumberdaya laut lainnya yang bukan menjadi tujuan penangkapan.

Dalam rangka optimalisasi pemanfaatan sumberdaya ikan layang (Decapterus) di perairan Laut Flores-Sulawesi Selatan dan upaya keberlangsungannya maka perlu adanya 
penentuan beberapa jenis alat tangkap yang cocok untuk setiap jenis ikan. Keuntungan yang diharapkan adalah nelayan mendapatkan hasil tangkapan sesuai dengan yang diharapkan, dan sumberdaya ikan tidak mengalami tekanan dari berbagai alat tangkap yang tidak produktif.

\subsection{Model Produksi Surplus}

Sebelum dilakukan analisis pendugaan potensi lestari (MSY) dan upaya tangkap optimum $\left(\mathrm{f}_{\mathrm{opt}}\right)$ terlebih dahulu ditentukan model yang cocok untuk dipergunakan dalam analisis lanjutan. Penentuan model tersebut didasarkan pada hubungan antara jumlah produksi dan nilai CPUE (model Schaefer) atau Ln CPUE (model Fox), hasil analisa pada Tabel 2.

Tabel 2. Perbandingan Nilai Intercept (a), Slope (b), dan Koefisien Determinasi (R2) Schaefer dan Fox

\begin{tabular}{ccc}
\hline Nilai & Schaefer & Fox \\
\hline$a$ & 0.053544 & -2.79922 \\
$b$ & $-4.63313 \mathrm{E}-08$ & $-2.14123 \mathrm{E}-06$ \\
$R^{2}$ & 0,502 & 0,784 \\
\hline \multicolumn{2}{l}{ Sumber : Data Olahan (2010) }
\end{tabular}

Berdasarkan analisis yang dilakukan, maka model Fox lebih cocok untuk gunakan pada analisis pendugaan potensi lestari (MSY) dan effort optimum $\left(f_{\text {opt }}\right)$ pada ikan layang di perairan Laut Flores-Sulawesi Selatan, karena nilai koefisien determinasi $\left(\mathrm{R}^{2}\right)$ mendekati angka 1 yaitu 0,784 , jika dibandingan dengan model Schaefer hanya sebesar 0,502 (Tabel 2).

\subsection{Potensi Lestari (MSY) dan Upaya Optimum ( $\left.\mathbf{f}_{\text {opt }}\right)$}

Berdasarkan hasil analisa regresi antara effort standar dan Ln CPUE (model Fox) maka diperoleh nilai parameter pendugaan sebagai berikut, yaitu : Ikan layang dengan nilai intercept (a) $=-2.7992209$ dan slop $(\mathrm{b})=-2.14123 \mathrm{E}-06$ (Gambar 2).

Sehingga membentuk persamaan Ln CPUE $=-2.7897951-2.176 \mathrm{E}-06 f$. Hubungan persamaan ini dapat diinterpretasikan bahwa bila dilakukan upaya penangkapan sebesar $f$ satuan per tahun maka akan mengurangi nilai produksivitas (CPUE) ikan layang sebesar 2.176 ton/tahun. Dengan mengetahui nilai intercept (a) dan slop (b), diperoleh pendugaan nilai potensi lestari (MSY) ikan layang di Laut Flores-Sulawesi
Selatan sebesar 10.456 ton/tahun, sedangkan nilai upaya penangkapan optimum $\left(f_{\text {opt }}\right)$ adalah sebesar 467.022 trip/tahun.

Pada gambar 3, terlihat hubungan antara upaya penangkapan (effort) dengan produksi ikan layang. Artinya dengan penambahan effort sampai 467.022 trip/tahun maka akan meningkatkan produksi maksimal sampai 10.456 ton/tahun. Sehingga untuk pemanfaatan sumberdaya ikan layang (Decapterus) secara berkelanjutan maka upaya penangkapan tidak boleh melebihi 467.022 trip/tahun dengan produksi maksimal lestari (MSY) 10.456 ton/tahun. Jika penambahan effort (trip panangkapan) melebihi effort optimum, maka produksi penangkapan cenderung akan mengalami penurunan di bawah nilai MSY.

\subsection{Tingkat Pemanfaatan dan Pengupayaan}

Berdasarkan hasil analisis model Fox, potensi lestari (MSY) ikan layang sebesar 10.456 ton/tahun dengan upaya tangkap optimum $\left(f_{\text {opt }}\right)$ sebanyak 467.022 trip/tahun. Tingkat pemanfaatan rata-rata periode 1999-2007 sebesar $76,6 \%$ dari nilai MSY dan tingkat pengupayaan sebesar 83,2 \% dari upaya tangkap optimum $\left(f_{o p t}\right)$ (Tabel 3). Artinya jika dilakukan penambahan tingkat pemanfaatan sebesar 23,4\% maka tingkat pengupayaan yang diperlukan sebesar $16,85 \%$, untuk pemanfaatan sumberdaya ikan layang secara berkelanjutan.

Perkembangan tingkat pemanfaatan periode 1999-2007 berkisar 49,3\%-96,9\% dan tingkat pengupayaan berkisar $30,5 \%-285,6 \%$. Dimana pada tahun 2006 tingkat pemanfaatan tertinggi sebesar 96,9\% dan tingkat pengupayaan sebesar $32,6 \%$. Dengan tingkat pemanfaatan ratarata sebesar $76,6 \%$ dapat diindikasikan bahwa sumberdaya ikan layang di Perairan laut FloresSulawesi Selatan, berada pada tahap "Padat Eksploitasi" sehingga perlu pemanfaatan secara hati-hati. Dengan nilai rata-rata tingkat pengupayaan sebesar $83,15 \%$ berarti upaya penangkapan sudah sangat tinggi meskipun belum melewati nilai effort optimum, namun terlihat bahwa pada tahun 1999 tingkat pengupayaan telah melewati nilai effort optimum sebesar 185,6\%, dan pada tahun 2002-2003 sebesar $5,9 \%$.

Tabel 3. Tingkat Pemanfaatan $\left(\mathrm{TP}_{\mathrm{c}}\right)$ dan Tingkat Pengupayaan $\left(\mathrm{TP}_{\mathrm{e}}\right)$ Ikan Layang di Perairan Laut Flores selama Periode 1999-2007. 


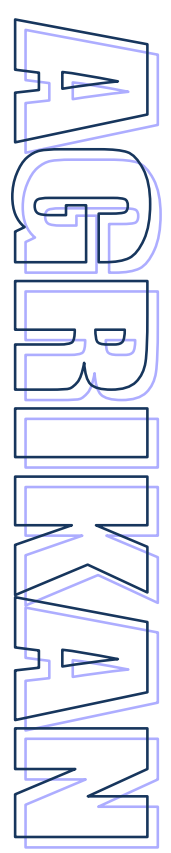

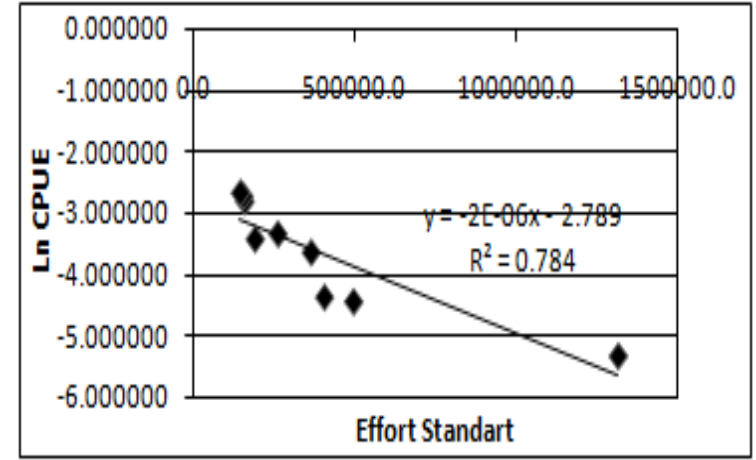

Gambar 2. Hubungan effort standar dan ln CPUE Ikan Layang tahun 1999-2007 (Model Fox)

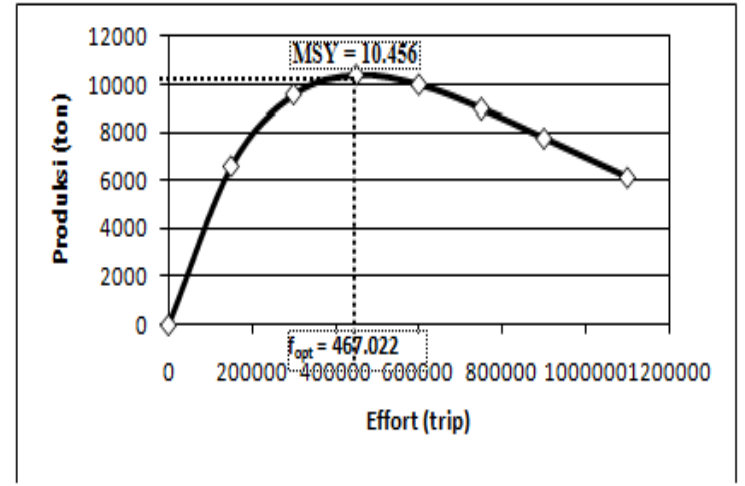

Gambar 3. Grafik Hubungan Antara Upaya Penangkapan (Effort) dengan Produksi Ikan Lavang di Perairan Laut Flores-Sulawesi Selatan Berdasarkan Model Fox.

\begin{tabular}{cccccc}
\hline Tahun & Catch (ton) & $\begin{array}{c}\text { Effort Std } \\
\text { (trip) }\end{array}$ & $\begin{array}{c}\text { CPUE } \\
\text { (ton/trip) }\end{array}$ & $\begin{array}{c}\text { Tingkat } \\
\text { Pemanfaatan (\%) }\end{array}$ & $\begin{array}{c}\text { Tingkat } \\
\text { Pengupayaan (\%) }\end{array}$ \\
\hline 1999 & $6.430,6$ & $1.333 .921,2$ & 0,005 & 61,5 & 285,6 \\
2000 & 6.184 .8 & $188.557,8$ & 0,033 & 59,2 & 40,4 \\
2001 & 5.149 .8 & $404.060,4$ & 0,013 & 49,3 & 86,5 \\
2002 & 5.860 .6 & $494.615,1$ & 0,012 & 56,1 & 105,9 \\
2003 & $9.595,3$ & $362.784,3$ & 0,026 & 91,8 & 105,9 \\
2004 & $9.274,8$ & $259.428,1$ & 0,036 & 88,7 & 55,5 \\
2005 & $9.494,6$ & $156.483,1$ & 0,061 & 90,8 & 33,5 \\
2006 & 10.135 .0 & $152.364,2$ & 0,067 & 96,9 & 32,6 \\
2007 & $9.952,8$ & $142.563,7$ & 0,070 & 95,2 & 30,5 \\
\hline Total & $72.078,3$ & $3.494 .778,0$ & 0,036 & 689,4 & 748,3 \\
\hline Rata-rata & $8.008,7$ & $388.308,7$ & 0,004 & 76,6 & 83,2 \\
\hline Sumber: Analisa Data Sekunder, 2010. & & & &
\end{tabular}

Berdasarkan hasil analisis data pada Tabel 3 , diketahui bahwa tingkat pengupayaan yang tinggi menurunkan nilai CPUE, artinya tingkat pengupayaan berbanding terbalik dengan nilai CPUE. Dengan demikian diperlukan pengontrolan terhadap tingkat pengupayaan untuk menghindari over fishing.

Rata-rata tingkat pemanfaatan sumberdaya ikan layang di perairan Laut Flores-Sulawesi Selatan belum mencapai nilai MSY, namun jika melihat nilai tingkat pemanfaatan dari tahun 2003-2007 (Tabel 2) sudah melewati nilai jumlah tangkapan yang diperbolehkan (JTB) yaitu $80 \%$ dari MSY (8.364,6 ton/tahun) dan hampir mendekati nilai MSY (10.456 ton/tahun) dengan kisaran (9.724,8-10.135,0 ton/tahun).

Dengan merujuk pada Tabel 3 terlihat terjadi fluktuasi hasil tangkapan akibat fluktuasi effort. Artinya peningkatan effort masih memberikan dampak positif terhadap peningkatan catch karena pemanfaatan masih dibawah nilai MSY dan $\mathrm{F}_{\text {opt }}$, meskipun demikian diperlukan upaya pengelolaan sumberdaya ikan layang di perairan Laut Flores, agar dapat dimanfaatkan secara optimal dan berkelanjutan.

Upaya pengelolaan sumberdaya ikan layang dapat dilakukan melalui pengaturan upaya penangkapan baik berupa jumlah trip maupun jumlah alat tangkap yang digunakan dalam mengeksploitasi serta pengaturan kuota penangkapan, untuk menghindari over exploitasi yang dapat menyebabkan overfishing secara biologi (biological overfishing) karena dapat melewati nilai maksimum lestari (MSY). Dimana menurut Widodo dan Suadi (2006), bahwa biological overfishing akan terjadi manakala tingkat upaya penangkapan dalam suatu perikanan tertentu telah melampaui tingkat yang diperlukan untuk menghasilkan potensi maksimum lestari (MSY), namun dapat dicegah dengan melakukan pengaturan upaya penangkapan dan pola penangkapan. 


\section{PENUTUP}

\subsection{Kesimpulan}

Berdasarkan hasil penelitian, maka dapat disimpulkan sebagai berikut :

1. Hasil analisis Produksi Surplus dengan menggunakan model Fox didapatkan nilai potensi lestari (MSY) sumberdaya ikan Layang (Decapterus) di perairan Laut FloresSulawesi Selatan adalah sebesar 10.456 ton/tahun, dengan upaya tangkap optimum $\left(f_{\text {opt }}\right)$ sebanyak 467.022 trip/tahun.

2. Tingkat pemanfaatan rata-rata periode 1999 2007 sebesar 76,60 \% dan upaya tangkap sebesar $83,15 \%$.
3. Status pemanfaatan sumberdaya ikan layang di perairan Laut Flores-Sulawesi Selatan sudah dikategorikan padat eksploitasi. Sehingga perlu kehati-hatian dalam upaya pemanfataannya.

\subsection{Saran}

Perlunya evaluasi tingkat pemanfaatan sumberdaya ikan layang secara berkala sebagai basis data dan sumber informasi dalam upaya pengelolaannya di perairan Laut Flores-Sulawesi Selatan melalui pengaturan upaya penangkapan untuk dapat dimanfaatakan secara berkelanjutan.

\section{DAFTAR PUSTAKA}

Astuti, E.M. 2005. Dimensi Unit Penangkapan Pukat Udang dan Tingkat Pemanfaatan Sumberdaya Udang di Perairan Laut Arafura. Skripsi. Departemen Pemanfaatan Sumberdaya Perikanan, Fakultas Perikanan dan Ilmu Kelautan.IPB. Bogor.

Dinas Kelautan dan Perikanan Sulawesi Selatan 1999-2007. Statistik Perikanan Provinsi Sulawesi selatan. Makassar.

Gulland JA. 1983. Fish Stock Assesment. A Manual of Basic Methods. John Wiley and Sons, Chichester-New York-Brisbane-Toronto-Singapore.

Imron, 2008. Pemanfaatan Sumberdaya Perikanan Demersal yang Berkelanjutan di Perairan Tegal Jawa Tengah. Disertasi. Departemen Pemanfaatan Sumberdaya Perikanan. Sekolah Pasca Sarjana. IPB. Bogor.

Najamuddin. 2004. Kajian Pemanfaatan Sumberdaya Ikan Layang (Decapterus spp) Berkelanjutan di Perairan Selat Makassar. Disertasi. Program Studi Ilmu Pertanian Program Pasca Sarjana. UNHAS Makassar.

Sparre P, Venema SC. 1999. Introduksi Pengkajian Stok Ikan Tropis, Buku 1: Manual. Pusat Penelitian dan Pengembangan Perikanan.

Taeran. I. 2007 Tingkat Pemanfaatan dan Pola Musim Penangkapan Beberapa Jenis Ikan Pelagis Ekonomis Penting di Provinsi Maluku Utara. Tesis. Departemen Pemanfaatan Sumberdaya Perikanan. Sekolah Pasca Sarjana. IPB. Bogor.

Widodo, J., Azis, K.A., Priyono,B.E., Tampubolon, H.H., Naamin, N dan Djamali, A. 1998. Potensi dan Penyebaran Sumberdaya Ikan Laut di Perairan Indonesia. Komisi Nasional Pengkajian Stok Sumberdaya Ikan Laut, LIPI. Jakarta.

Widodo, J. dan Suadi. 2006. Pengelolaan Sumberdaya Perikanan Laut. Penerbit : Gajah Mada University Press. Yogyakarta. 